\title{
PRODUCTION OF BIOSURFACTANT IN 2L BIOREACTOR USING SLUDGE PALM OIL AS A SUBSTRATE
}

\author{
P. JAMAL, M.Z. AlaM, E.A. ZAINUDDIN AND W.M.F.W. NAWAWI \\ Bioenvironmental Engineering Research Unit (BERU), Department of Biotechnology \\ Engineering, Faculty of Engineering, International Islamic University Malaysia (IIUM), \\ P.O. BOX 10, 50728 Kuala Lumpur, Malaysia.
}

jparveen@iium.edu.my

\begin{abstract}
In this study, sludge palm oil was utilized as a raw material for process optimization in a stirred tank bioreactor for the biosurfactant production. Optimized parameters include temperature, agitation and aeration while the $\mathrm{pH}$ and media compositions such as $\mathrm{NaNO}_{3}, \mathrm{NaCl}, \mathrm{FeSO}_{4}$, Meat extract, and glucose have been fixed from the previous study. The design of this research was made by using the DesignExpert software (2 level factorial design). Surface tension was used as indirect indicator for biosurfactant production. After model validation, yield of biosurfactant was found to be highest when surface tension was at its lowest value $(<24 \mathrm{mN} / \mathrm{m})$ at temperature of $30^{\circ} \mathrm{C}$, agitation $300 \mathrm{rpm}$ and around $0.5 \mathrm{vvm}$ of aeration with percentage error less than $10 \%$ between observed value and predicted value. The finding in this research can be applied to produce biosurfactant in large amount from the less expensive material such as sludge palm oil by using the same optimized model equation.
\end{abstract}

ABSTRAK: Dalam kajian ini, enapcemar kelapa sawit digunakan sebagai bahan mentah untuk pengoptimuman proses dalam bioreaktor bagi penghasilan biosurfactant. Parameter yang dioptimumkan termasuk suhu, pergolakan dan pengudaraan manakala pH dan komposisi media seperti $\mathrm{NaNO}_{3}, \mathrm{NaCl}, \mathrm{FeSO}_{4}$, ekstrak daging, dan glukos telah ditetapkan daripada kajian sebelumnya. Reka bentuk kajian ini telah dilakukan dengan menggunakan perisian Design Expert (2 Level factorial design). Tegangan permukaan digunakan sebagai penunjuk tidak langsung untuk penghasilan biosurfactant. Selepas pengesahan, hasil biosurfactant didapati terbanyak apabila tegangan permukaan pada nilai terendah $(<24 \mathrm{mN} / \mathrm{m})$ pada suhu $30^{\circ} \mathrm{C}$, pergolakan $300 \mathrm{rpm}$, dan sekitar $0.5 \mathrm{vvm}$ pengudaraan dengan margin perbezaan kurang daripada $10 \%$ antara nilai sebenar cerapan dan nilai yang diramalkan. Penemuan dalam kajian ini boleh digunakan untuk menghasilkan biosurfactant dalam jumlah yang besar dari bahan yang murah seperti enapcemar kelapa sawit dengan menggunakan model optimum yang sama.

KEYWORDS: biosurfactant; sludge palm oil; process optimization; factorial design

\section{INTRODUCTION}

Nowadays, the usage of surfactant is very popular in various fields. Examples of an area that have been utilized this compound includes cosmetics, pharmaceuticals, petroleum, petrochemicals, food, beverages, environmental control, and agrochemicals [1]. Current worldwide surfactant markets estimates around US $\$ 9.4$ billion per annum, and their demand is expected to increase at a rate of $35 \%$ toward the end of the century [2]. 
However, the emergence of biosurfactant, which have the capability to reduce surface and interfacial tension with low toxicity, with high specificity and biodegradability, led to an increasing interest on these microbial products as alternatives to chemical surfactants. Biosurfactants are microbial compounds with a pronounced surface activity that can exhibit a wide variety of chemical structures, such as glycolipids, lipopeptides, polysaccharide protein complexes, protein-like substances, lipopolysaccharides, phospholipids, fatty acids and neutral lipids [3].

Nevertheless, biosurfactants are still unable to compete with chemically synthesized surfactants in the market. This may be due to their high production costs in relation to inefficient bioprocessing method available, poor strain productivity and the need to use of expensive substrates [4]. Despite possessing many commercially attractive properties and clear advantages compared to their synthetic counterparts, the production of microbial surfactants on a commercial scale has not been realized because of their low yields and high production costs. Moreover, biosurfactants are difficult to produce as cost effective for several reasons such as overproducing strains of bacteria are rare and those found generally display a very low productivity so that complex media need to be applied [5].

In this study, production of biosurfactant was initiated by optimizing the growth of the potential biosurfactant producers as the factor of several process parameters such as temperature, agitation and, aeration in $2 \mathrm{~L}$ bioreactor.

\section{MATERIAL AND METHODS}

\subsection{Microorganisms and Raw Materials}

The Pseudomonas aeruginosa involved in this study has been previously isolated from hydrocarbon contaminated site and cultured on nutrient agar for future usage [6]. This isolated bacterium was assumed to be able to degrade hydrocarbon from the sample. The raw material (sludge palm oil) have been collected from Oil Palm Industry, Dengkil, Malaysia. It was then stored in an oven at $60^{\circ} \mathrm{C}$ to ensure the sludge maintain its liquid form.

\subsection{Mineral Salt Medium}

The compositions of the media in $1 \mathrm{~L}$ working volume were: glucose $(4 \%)$, meat extract $(0.075 \%), \mathrm{FeSO}_{4}(0.01 \%)$, sodium nitrate $(0.04 \%), \mathrm{NaCl}(0.01 \%)$ and sludge palm oil $(2 \%)$. The media was pre-autoclaved at $121^{\circ} \mathrm{C}$ and $101.3 \mathrm{kPa}$ for $15 \mathrm{~min}$.

\subsection{Inoculum Preparation for Stirred Tank Bioreactor}

A fresh single pure colony of each bacterial isolate was transferred aseptically from agar plate into liquid medium using a sterile wire loop and incubated in a rotary shaker at $37^{\circ} \mathrm{C}$ and $300 \mathrm{rpm}$ for 6 hours. The $100 \mathrm{ml}$ inoculum is used since the working volume is 1 L.

\subsection{Du Nouy Methodology}

Surface tension measurement was measured using a KSV Sigma 702 tensiomenter. All measurements were made on the cell-free broth obtained by centrifuging the culture at $10000 \mathrm{rpm}$ for $15 \mathrm{~min}$. Ten milliliter of each cell free broth was transferred into a clean 20 $\mathrm{ml}$ beaker and placed onto the tensiometer platform. A platinum wire ring was submerged into the solution and then slowly pulled through the liquid-air interface, to measure the surface tension $(\mathrm{mN} / \mathrm{m})$. Between each measurement, the platinum wire ring was rinsed with water and flamed with Bunsen burner. 


\subsection{Optimization Study for Process Conditions}

Optimization of process condition was done using three factors that were temperature $\left({ }^{\circ} \mathrm{C}\right)$, agitation (rpm), and aeration (vvm) in order to determine the optimum conditions for the maximum yield of biosurfactant by using stirred tank bioreactor. Other parameters such as $\mathrm{pH}$ and media compositions used in the process were fixed according to the optimum value of production of biosurfactant based on the previous study.

The experimental design was selected from Design-Expert software (2 level Factorial) for determination of optimum process conditions for production of biosurfactant. Ten experiments were conducted and the range of which has been shown in Table 1.

Table 1: The range of parameters used for design of experiment.

\begin{tabular}{lll}
\hline \multirow{2}{*}{ Factors } & \multicolumn{2}{c}{ Level } \\
\cline { 2 - 3 } & -1 & 1 \\
\hline Temperature $\left({ }^{\circ} \mathrm{C}\right)$ & 30 & 40 \\
Agitation $(\mathrm{rpm})$ & 100 & 300 \\
Aeration $(\mathrm{vvm})$ & 0.5 & 2.0 \\
\hline
\end{tabular}

\section{RESULTS AND DISCUSSION}

The time needed to achieve the maximum concentration of biosurfactant is correlated indirectly with the surface tension reduction. Thus, surface tension was used as a main response due to the fact there was a big difference between iterations. Lowering of surface tension is directly correlated to higher biosurfactant concentration.

Table 2 presents the design matrix of the variables along with the surface tension as a response. Table 3 shows the statistical results obtained after analyzing by Design Expert. Analysis of variance (ANOVA) was performed in order to find the effect and contribution of each variable. Both Fisher variation ratio (F-value) and p-value from ANOVA were used to confirm the significance of variables studied.

Data were best fitted by the following equation (Eq. 1):

$$
\mathrm{Y}=26.13-0.66 \mathrm{~A}-0.94 \mathrm{~B}-0.92 \mathrm{C}+1.29 \mathrm{AB}-0.62 \mathrm{AC}
$$

where $\mathrm{Y}$ is the predicted response (surface tension) and $\mathrm{A}, \mathrm{B}, \mathrm{C}$ are the coded values for temperature, agitation and aeration respectively. During the experiment, the surface tension reached the lowest values at run 10 where temperature $=30^{\circ} \mathrm{C}$, agitation $=100$ rpm, aeration $=2.0 \mathrm{vvm}$. 
Table 2: 2 Level Factorial experimental design matrix with observed and predicted values of surface tension.

\begin{tabular}{cccccc}
\hline & \multirow{2}{*}{$\begin{array}{c}\text { Factor } 1 \\
\text { Run }\end{array}$} & $\begin{array}{c}\text { Factor } 2 \\
\text { agitation } \\
\text { Celsius }\end{array}$ & $\begin{array}{c}\text { Factor } 3 \\
\text { aeration } \\
\text { rpm }\end{array}$ & vvm & \multicolumn{2}{c}{$\begin{array}{c}\text { Surface tension } \\
\mathrm{mN} / \mathrm{m}\end{array}$} \\
\cline { 5 - 6 } & & 200 & 1.25 & 27.21 & Observed \\
2 & 35 & 300 & 2.00 & 23.78 & Predicted \\
3 & 30 & 100 & 0.50 & 25.33 & 24.26 \\
4 & 40 & 300 & 2.00 & 29.21 & 28.73 \\
5 & 40 & 300 & 0.50 & 24.45 & 24.29 \\
6 & 40 & 100 & 2.00 & 28.84 & 29.32 \\
7 & 40 & 300 & 0.50 & 26.82 & 26.66 \\
8 & 30 & 100 & 0.50 & 24.13 & 24.80 \\
9 & 30 & 200 & 1.25 & 25.47 & 24.80 \\
10 & 35 & 100 & 2.00 & 23.43 & 23.59 \\
\hline
\end{tabular}

Table 3: Analysis of variance (ANOVA) for response surface quadratic model.

\begin{tabular}{llllll}
\hline Source & $\begin{array}{l}\text { Sum of } \\
\text { Square }\end{array}$ & $\begin{array}{l}\text { Degree of } \\
\text { Freedom }\end{array}$ & Mean square & F-value & Prob>F \\
\hline Model & 33.75 & 5 & 6.75 & 10.55 & $0.0404^{*}$ \\
$\mathrm{~A}$ & 3.45 & 1 & 3.45 & 5.39 & 0.1030 \\
$\mathrm{~B}$ & 7.09 & 1 & 7.09 & 11.08 & $0.0448^{*}$ \\
$\mathrm{C}$ & 6.72 & 1 & 6.72 & 10.50 & $0.0478^{*}$ \\
$\mathrm{AB}$ & 13.39 & 1 & 13.39 & 20.94 & $0.0196^{*}$ \\
$\mathrm{AC}$ & 3.09 & 1 & 3.09 & 4.83 & 0.1155 \\
Curvature & 2.85 & 1 & 2.85 & 4.45 & 0.1254 \\
Residual & 1.92 & 3 & 0.64 & & \\
Lack of Fit & 1.02 & 2 & 0.51 & 0.57 & 0.6841 \\
Pure Error & 0.90 & 1 & 0.90 & & \\
Corrected & 38.49 & 9 & & & \\
Total & & & & & \\
\hline
\end{tabular}

*P value $<0.05$ indicate the model term is significant

$$
\mathrm{R}=0.9727, \mathrm{R}^{2}=0.9462, \mathrm{CV}=3.09 \%
$$

ANOVA was used to determine the relative importance of various factors/ parameters. Both Fisher variation ratio $(F$-value) and $p$-value (Prob $>$ F) from ANOVA were used to confirm the significance of variables studied. The greater F-value indicated that the variables explained adequately the variation in the data about its mean, and the estimated variable effects were real. Small $p$-values were associated with a larger $F$-value because they imply that the effects were much greater than its standard error. The smaller the magnitude of the $p$-value, the more significant is the corresponding coefficient [7]. Values of "Prob > F" which is 0.0404 and less than 0.0500 indicate model terms are significant. In this case B, C, AB is significant model terms. Values greater than 0.1000 indicate the model terms are not significant. In this case, $\mathrm{A}$ and $\mathrm{AC}$ are not significant. The "Curvature F-value" of 4.45 implies the curvature as measured by difference between the average of the center points and the average of the factorial points in the design space 
is not significant relative to the noise. There is a $12.54 \%$ chance that a "Curvature Fvalue" this large could occur due to noise. The "Lack of Fit F-value" of 0.57 implies that the lack of fit for the model is not significant relative to the pure error.

The correlation measures for the estimation of the regression equation are the multiple correlation coefficients and the determination coefficient $\left(R^{2}\right)$. The value of $\mathrm{R}^{2}=$ 0.9462 indicated that only $5.38 \%$ of total variations were not explained by the model. Since the closer the value of $\mathrm{R}^{2}$ is to 1 , the better is the correlation between the observed and the predicted values. The value of $\mathrm{R}^{2}$ was satisfied because it indicated that the lackof-fit of this model was "not significant". Then, a lower value of $\mathrm{CV}=3.09 \%$ signified a greater reliability of the experiments performed and indicated that the model can be used to navigate the design space.

The model provided few solutions for optimum process conditions with predicted minimal surface tension. Thus, in order to verify this model prediction, more experiments were carried out using the optimized medium. Only two of them were chosen to validate the accuracy and precision of the optimized model. Table 4 shows the results from validation experiments in term of observed and predicted surface tension.

Table 4: Results for validation experiments.

\begin{tabular}{llllll}
\hline Run & Temperature & Agitation & Aeration & \multicolumn{2}{c}{ Surface tension $(\mathrm{mN} / \mathrm{m})$} \\
\cline { 5 - 6 } & & & & Observed & Predicted \\
\hline 1 & 30 & 300 & 0.58 & 23.57 & 24.82 \\
2 & 30 & 300 & 0.53 & 23.44 & 24.84 \\
\hline
\end{tabular}

The surface tension achieved experimentally under the statistically optimum conditions: $23.57 \mathrm{mN} / \mathrm{m}$ (run 1), which was close to the $24.82 \mathrm{mN} / \mathrm{m}$, predicted by the model with $5.03 \%$ error difference between observed and predicted value. Run 2 also showed small percentage error at $5.63 \%$. By comparing with another study which utilized oily substrate, it was observed that the result obtained in this research was in accordance with the result obtained by using olive oil mill effluent and frying oil as a substrate that gave surface tension of $30 \mathrm{mN} / \mathrm{m}$ and $32-34 \mathrm{mN} / \mathrm{m}$ respectively [8]. Due to low percentage error between observed and predicted value, the optimized model equation can be used to develop further studies for biosurfactant production that will utilize sludge palm oil at larger scale.

\section{CONCLUSION}

The present work demonstrated the effect of three process conditions namely temperature, agitation rate and aeration towards biosurfactant production. Two Level Factorial with 3 Full Factorials design from statistical software package Design-Expert (Version 6.0.8, Stat-Ease, Minneapolis, USA) was used to design the process conditions and for analyzing the experiment. The analysis of experiment was conducted and the equation, which described the model, was used to find the optimized value of process conditions. After validation study, the optimized process conditions was found at temperature $30^{\circ} \mathrm{C}$, agitation of $300 \mathrm{rpm}$ with $0.58 \mathrm{vvm}$ aeration with corresponding surface tension of 23.57. Since Malaysia is one of the main palm oil producers in the world, this project provides a ground in an effective way for the management of palm oil sludge as well as to produce a cost effective valueable product.This bioreactor scale study 
offered the basis of scale up for the production scale of biosurfactant before proceeding to industrial scale.

\section{REFERENCES}

[1] N. Kosaric. "Biosurfactant in industry". Pure Appl. Chem., Vol 64, no. 11, 1731-1737, 1992.

[2] J. D. Desai and I.M. Banat. "Microbial production of surfactants and their commercial potential". Microbiol. Mol. Biol. Rev., Vol 61, no.1, 47-64, 1997.

[3] L. R. Rodrigues, J. A. Teixera, H. C. Mei, and R. Olievera. "Physiochemical and functional characterization of a biosurfactant produced by Lactococcus lactis". Colloids and Surface B, Vol. 49, 78-85, 2006.

[4] S. S. Cameotra and R. S. Makkar. "Synthesis of biosurfactants in extreme conditions". Appl. Microbiol. Biotechnol., Vol 50, 520-529, 1998.

[5] A. Fiechter. "Biosurfactant: moving towards industrial application". Trends Biotechnol., Vol 10, 208-217, 1992.

[6] N. Fathiah, Production of biosurfactant using microbial fermentation, final year project thesis, Biochemical and Biotechnology Engineering, International Islamic University Malaysia, Malaysia, 2007.

[7] W. M. F. W. Nawawi, P.Jamal, and M. Z. Alam, "Utilization of sludge palm oil as a novel substrate for biosurfactant production". Bioresource Technol., Vol 101, no. 23, 9241-9247, 2010.

[8] V. Pruthi and S. S. Cameotra. "Production of a biosurfactant exhibiting excellent emulsification and surface active properties by Serratia marcescenes". World J. Microbiol. Biotechnol. Vol 13, 133-135, 1997. 